\title{
Nucleic acid oxidation is associated with biomarkers of neurodegeneration in CSF in people with HIV
}

Ronald J. Ellis, MD, PhD, David J. Moore, PhD, Erin E. Sundermann, PhD, Robert K. Heaton, PhD, Sanjay Mehta, MD, Todd Hulgan, MD, David Samuels, PhD, Jerel A. Fields, PhD, and Scott L. Letendre, MD

Neurol Neuroimmunol Neuroinflamm 2020;7:e902. doi:10.1212/NXI.0000000000000902

\section{Abstract}

\section{Objective}

To determine whether oxidative stress in virologically suppressed people with HIV (PWH) may contribute to or result from neurodegeneration, we measured 7,8-dihydro-8-oxoguanine (8-oxo-dG), a marker of DNA damage due to oxidative stress, and markers of age-related neurodegeneration, specifically, reduced levels of CSF A $\beta-42$, and elevated CSF total tau and neurofilament light (NFL).

\section{Methods}

This cross-sectional study prospectively enrolled participants at 6 US centers in the CNS HIV Antiretroviral Effects Research study. Inclusion criteria included HIV+ with a plasma level of HIV RNA $\leq 50$ copies/mL. Exclusions included significant CNS confounding conditions. Measurements of total tau and $A \beta-42$ were performed by bead suspension array. NFL and 8 -oxo-dG were measured using ELISA.

\section{Results}

Participants were $53 \mathrm{PWH}$, mean age 55 ( \pm 9.3$)$ years, 19\% women, and $48 \%$ non-Hispanic White. Higher 8-oxo-dG correlated with markers of $\mathrm{AD}$-related neurodegeneration including lower CSF A $\beta-42(\mathrm{r}=-0.34 ; p=0.012)$ and higher CSF NFL $(\mathrm{r}=0.39 ; p=0.0091)$ and total tau $(\mathrm{r}=0.6696 ; p<0.0001)$. Relationships remained after adjusting for demographic variables. Levels of protein carbonyls, a marker of protein oxidation, were not related to neurodegeneration markers.

\section{Conclusions}

Among virologically suppressed PWH, nucleic acid oxidation was associated with standard CSF biomarkers of neurodegeneration. Potential sources of oxidative stress in $\mathrm{PWH}$ include low-level HIV replication, inflammation, mitochondrial dysfunction, and specific antiretroviral drugs. Results suggest that the higher levels of oxidative stress among PWH may play a role in neurodegeneration.

\section{Classification of evidence}

This study provides Class II evidence that among virologically suppressed PWH, nucleic acid oxidation is associated with standard CSF biomarkers of neurodegeneration.

\author{
Correspondence \\ Dr. Ellis \\ roellis@ucsd.edu
}

MORE ONLINE

$\rightarrow$ Class of Evidence

Criteria for rating therapeutic and diagnostic studies

NPub.org/coe 


\section{Glossary}

8-oxo-dG = 7,8-dihydro-8-oxoguanine; $\mathbf{A D}=$ Alzheimer disease; ARV = antiretroviral; CHARTER = CNS HIV Antiretroviral Effects Research; NFL = neurofilament protein; $\mathbf{P W H}=$ people with HIV; ROS = reactive oxygen species.

Age-related neurodegeneration has taken on increasing importance in people with HIV (PWH) due to the increased longevity resulting from successful antiretroviral therapy. Researchers expect that Alzheimer disease (AD) will become increasingly common in $\mathrm{PWH}$ due to their longer lifespan. Oxidative stress is common in HIV, even among virologically suppressed individuals. ${ }^{1} \mathrm{HIV}$ and $\mathrm{AD}$ are both associated with oxidative stress and the resulting DNA damage as indexed by a marker of oxidatively damaged guanine, increased 7,8-dihydro-8oxoguanine (8-oxo-dG) levels. In HIV brains, lower volume of gray matter from selected brain areas (e.g., hippocampus and pallidum) is associated with lower levels of mitochondrial 8oxoG in serum. ${ }^{2}$ Moreover, an increase in 8-oxo-dG in nuclear DNA is accompanied by a decrease in the mitochondrial DNA content observed in the frontal cortex. ${ }^{3}$ Animal studies show that antiretrovirals (ARVs) also are associated with oxidative stress through the generation of oxidative radicals and depletion of antioxidants and antioxidant enzymes, leading to mitochondrial damage in the brain. ${ }^{4}$ In particular, dideoxynucleoside ARVs produce mitochondrial dysfunction and oxidative stress. ${ }^{5}$ A magnetic resonance spectroscopy study found that exposure to dideoxynucleoside ARVs was associated with reductions in $\mathrm{N}$-acetyl aspartate in the brain, possibly as a result of depleted brain mitochondria and/or alterations in cellular respiration. ${ }^{6}$

Similarly, oxidative stress in $\mathrm{AD}$ leads to nucleic acid and protein damage. ${ }^{7}$ Proteolytic processing of the amyloid precursor protein via amyloidogenic pathways yields neurotoxic and oxidative stress-producing $A \beta-42$ peptide, which is deposited in amyloid plaques. Such increased amyloid deposition in the brain leads to a reduction in $A \beta-42$ in CSF. Increased levels of oxidized bases in nuclear and mitochondrial DNA in temporal, parietal, and frontal lobes have been reported in $\mathrm{AD}^{8}$ Increased levels of 8-hydroxyguanine have even been detected in the hippocampus in preclinical stages of $\mathrm{AD} .^{9} \mathrm{~A} \beta-42$ also may directly disrupt mitochondria function and contribute to the deficiency of energy metabolism and neuronal death seen in $\mathrm{AD} .{ }^{10}$ Oxidative stress may contribute to the hyperphosphorylation and polymerization of tau. Cells overexpressing tau protein had increased susceptibility to oxidative stress. ${ }^{11}$

Among frequently used biomarkers of neurodegeneration are the light subunit of the neurofilament protein (NFL), a major structural element of myelinated axons. NFL concentration in CSF is a sensitive marker of neuronal damage in several neurologic diseases, ${ }^{12}$ and CSF NFL levels are substantially increased in PWH with HIV-associated dementia compared with HIV-uninfected individuals. ${ }^{13,14}$

To address possible relationships between oxidative stress and neurodegeneration in HIV, we measured 8-oxo-dG, $A \beta-42$, total tau, and NFL in CSF and plasma in PWH. Because of the close relationship between oxidative stress and neurodegeneration in other disorders such as $\mathrm{AD}$, we hypothesized that increased CSF 8-oxo-dG would be related to higher total tau and NFL, but lower $A \beta-42$, and that these relationships would be absent for plasma.

\section{Methods}

\section{Participants}

This cross-sectional study prospectively enrolled $53 \mathrm{PWH}$ between May 2016 and April 2018 at 6 university-based centers (St. Louis, Galveston, Baltimore, New York, Seattle, and San Diego) in the CNS HIV Antiretroviral Effects Research (CHARTER) Aging study, which has been described in detail previously. ${ }^{15}$ To enhance representativeness, CHARTER inclusion criteria were broad: HIV infection and willingness to undergo the study assessments were required and comorbidities such as past substance abuse were permitted. Exclusions were any substance use disorder in the past 6 months, uncontrolled major psychiatric disorders, untreated hepatitis $\mathrm{C}$ infection, active opportunistic infections, major neurologic conditions unrelated to HIV such as Parkinson disease or MS and uncontrolled epilepsy or inability to cooperate with a full day of clinical evaluation. Samples were selected based on viral suppression (plasma HIV RNA $<50$ copies), and available sample at the time assays were performed.

\section{Standard protocol approvals, registrations, and patient consents}

All participants signed informed consent documents approved by their respective local institutional review boards.

\section{Primary research question}

To determine whether oxidative stress in virally suppressed $\mathrm{PWH}$ is associated with markers of age-related neurodegeneration.

\section{Classification of evidence}

Class II.

\section{Biomarkers}

Measurements of total tau and $A \beta-42$ in plasma and CSF were performed by bead suspension array (Milliplex FLEXMAP 3D). Protein carbonyls and 8-oxo-dg were measured by ELISA (Trevigen, MD). NFL was measured using a commercially available kit (colorimetric ELISA; Tecan, Switzerland).

\section{Additional clinical and laboratory assessments} Comprehensive neuromedical assessments were performed. These assessments included vital signs, neurologic and physical examination, collection of medical history including 
Table Demographic and HIV disease characteristics of the study participants

\begin{tabular}{ll}
\hline Age, $\mathbf{y}($ mean \pm SD) & $55.0(9.3)$ \\
\hline Education & $13.1(2.3)$ \\
\hline Female sex (N, \%) & $10(18.9 \%)$ \\
\hline Non-Hispanic White race/ethnicity (N, \%) & $25(48.1 \%)$ \\
\hline CD4 nadir (median, IQR) & $115(28,196)$ \\
\hline Current CD4 (median, IQR) & $568(311,751)$ \\
\hline History of d-drug exposure (N, \%) & $33(62.3 \%)$ \\
\hline
\end{tabular}

Abbreviations: IQR = interquartile range; nadir, lowest historical level of blood $\mathrm{CD} 4^{+} \mathrm{T}$ cells.

ARV regimen, and collection of blood and CSF. Routine clinical assays, such as blood CD4 ${ }^{+} \mathrm{T}$-cell count and CSF total protein, were measured in the Clinical Laboratory Improvement Amendments-certified laboratory at the University of California, San Diego Medical Center. HIV RNA levels were measured in CSF and plasma by real-time PCR with a lower quantification limit of 50 copies/mL (Abbott Diagnostics, Des Plaines, IL). A comprehensive neuropsychological test battery was also administered to assess cognitive function in 7 domains commonly affected by HIV: verbal fluency, working memory, processing speed, verbal and visual learning, delayed recall, executive function, and complex motor function as previously described. ${ }^{15}$

\section{Statistics}

Only participant records with complete data were used. Demographics, medical history, and HIV disease characteristics were summarized using means andSDs, medians and interquartile ranges, or counts and percent as appropriate. To evaluate potential biases, confounds examined in multivariable models included demographics, disease characteristics, and past exposure to peripherally neurotoxic dideoxynucleosides (d-drugs) such as stavudine. $\log _{10}$ transformations were applied to biomarker measures to improve symmetry and normality of distributions. Correlations among biomarkers were assessed using Pearson $r$. Multivariable regressions were used to assess the impact of potential covariates.

\section{Data availability}

All individual deidentified participant data from this study, along with the clinical protocol, will be shared with qualified researchers on request to CHARTER. Qualified researchers include those who agree to use the shared study data and materials ethically and exclusively for prespecified biomedical research, the results of which will be made public promptly on their generation.

\section{Classification of evidence review}

This study provides Class II evidence that among virologically suppressed PWH, nucleic acid oxidation is associated with standard CSF biomarkers of neurodegeneration. The study is rated Class II because of the retrospective cohort design.

\section{Results}

Participants were $53 \mathrm{PWH}$, mean age 55 ( \pm 9.3$), 19 \%$ women, $48 \%$ non-Hispanic White, and all with plasma HIV RNA $<50$ copies $/ \mathrm{mL}$. The table details demographic and clinical characteristics of the sample.

\section{Biomarker correlations}

Total tau and NFL levels were strongly correlated $(\mathrm{r}=0.56$; $p<$ $0.0001)$. Lower $A \beta-42$ levels were related to higher total tau ( $\mathrm{r}$ $=-0.01 ; p=0.025)$, but were not related to NFL $(\mathrm{r}=0.019 ; p<$ 0.90 ). Lower CSF $A \beta-42$ (typically associated with $\mathrm{AD}$ in the general population) was related to higher 8-oxo-dG levels ( $p=$ 0.012 ; figure 1). Higher CSF NFL $(p=0.007)$ and total tau ( $p$ $=0.0001)$ were associated with higher 8-oxo-dG levels. None of the plasma biomarker levels was associated with 8-oxo-dG. Plasma levels of $\mathrm{A} \beta-42$ and 8-oxo-dG were unrelated. NFL and total tau were not measured in plasma due to limitations in

Figure 1 Intercorrelations between the markers of neurodegeneration, NFL, A $\beta-42$ and total tau

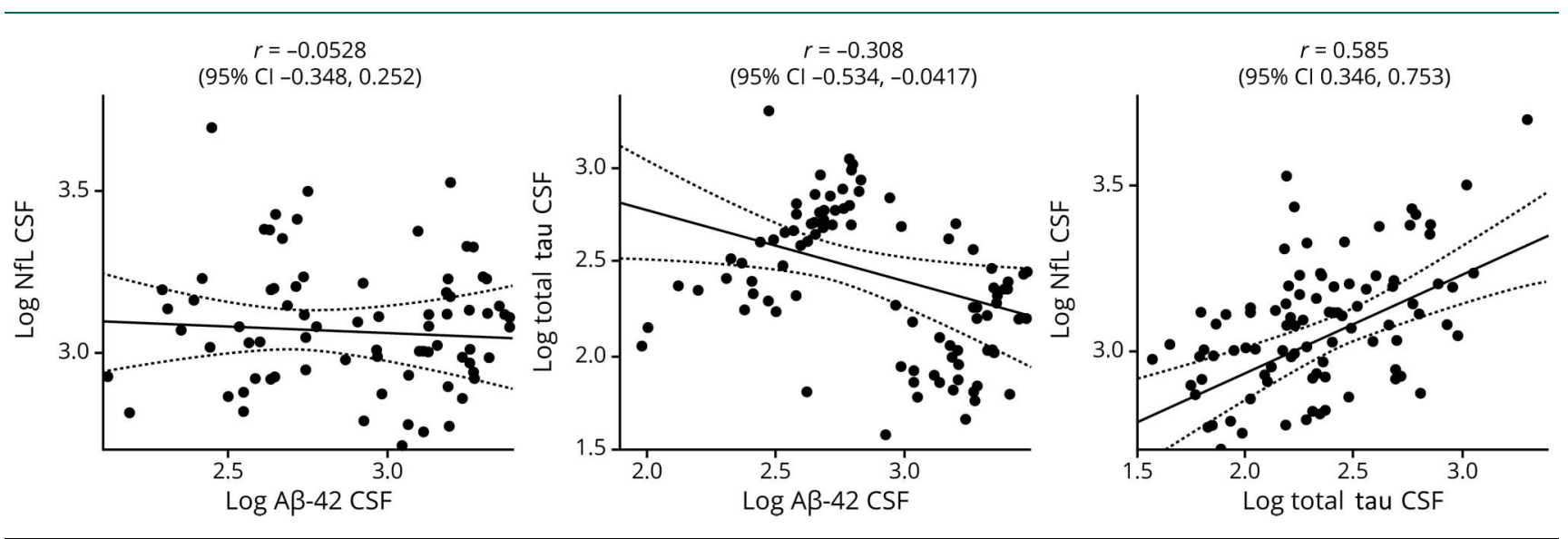


Figure 2 Levels of 8-oxo-dG as compared to biomarkers of neurodegeneration, NFL, A $3-42$ and total tau
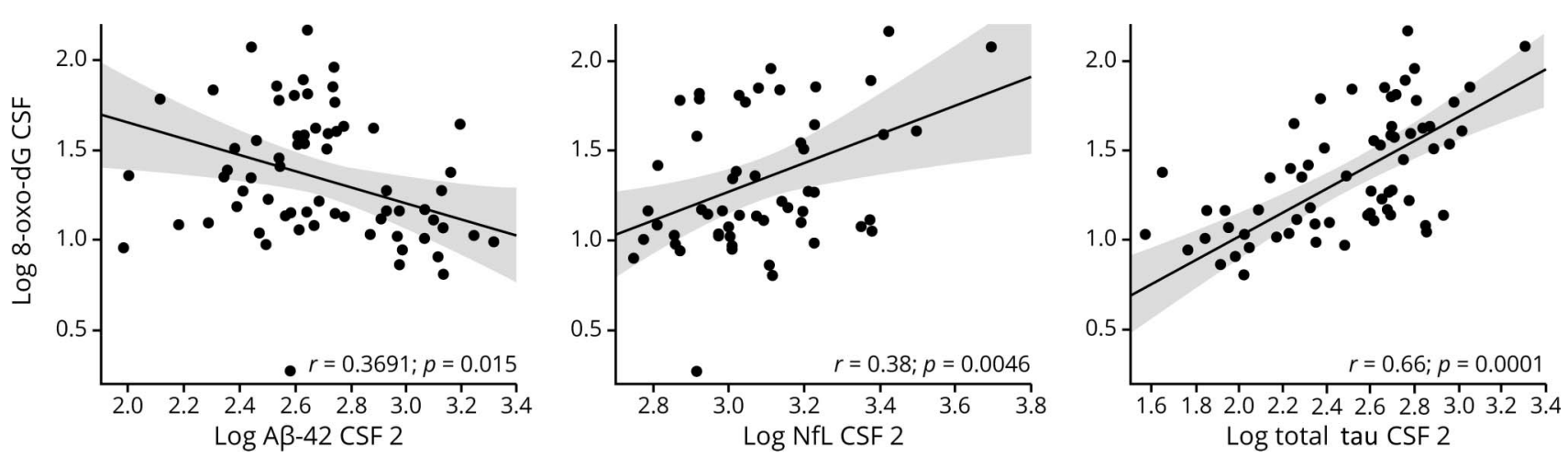

assay sensitivity. NP global and domain performance were not related to any of the biomarkers (figures 2 and 3).

\section{Potential demographic and} disease confounders

Men had higher CSF NFL (3.10 \pm 0.21 vs $2.95 \pm 0.12 ; p=$ $0.049)$ and $A \beta-42(2.73 \pm 0.26$ vs $2.53 \pm 0.36 ; p=0.042)$ than women (figure 4). Hispanics (3.04 \pm 0.43 ) had higher $A \beta-42$ than Black participants $(2.60 \pm 0.29 ; p=0.021)$ and White participants $(2.73 \pm 0.22 ; p=0.16)$. Higher 8 -oxo-dG was marginally associated with older age $(r=0.268 ; 95 \% \mathrm{CI}$, -0.0022 , 0.502). Furthermore, in a multivariable model predicting CSF Ab-42 from 8-oxo-dG and age, age was not significant $(p=0.209)$, whereas 8 -oxo-dG remained significant $(p=0.00613)$. In a multivariable model predicting total tau from 8-oxo-dG and age, both age $(p=0.00099)$ and 8-oxo-dG $(p<0.00001)$ were significant. In a multivariable model predicting NFL from 8-oxo-dG and age, both age $(p=0.00007)$ and 8-oxo-dG were significant $(p=0.0366)$. Thus, age was not a significant confounder of the relationships reported here. Nadir and current CD4 were not related to 8-oxo-dG levels. PWH with a history of d-drug exposure had higher 8-oxo-dG levels, but cumulative d-drug exposure was not related to 8-oxodG levels. Relationships of $A \beta-42$, total tau and NFL to 8-oxo-

Figure 3 Associations between age and biomarker levels
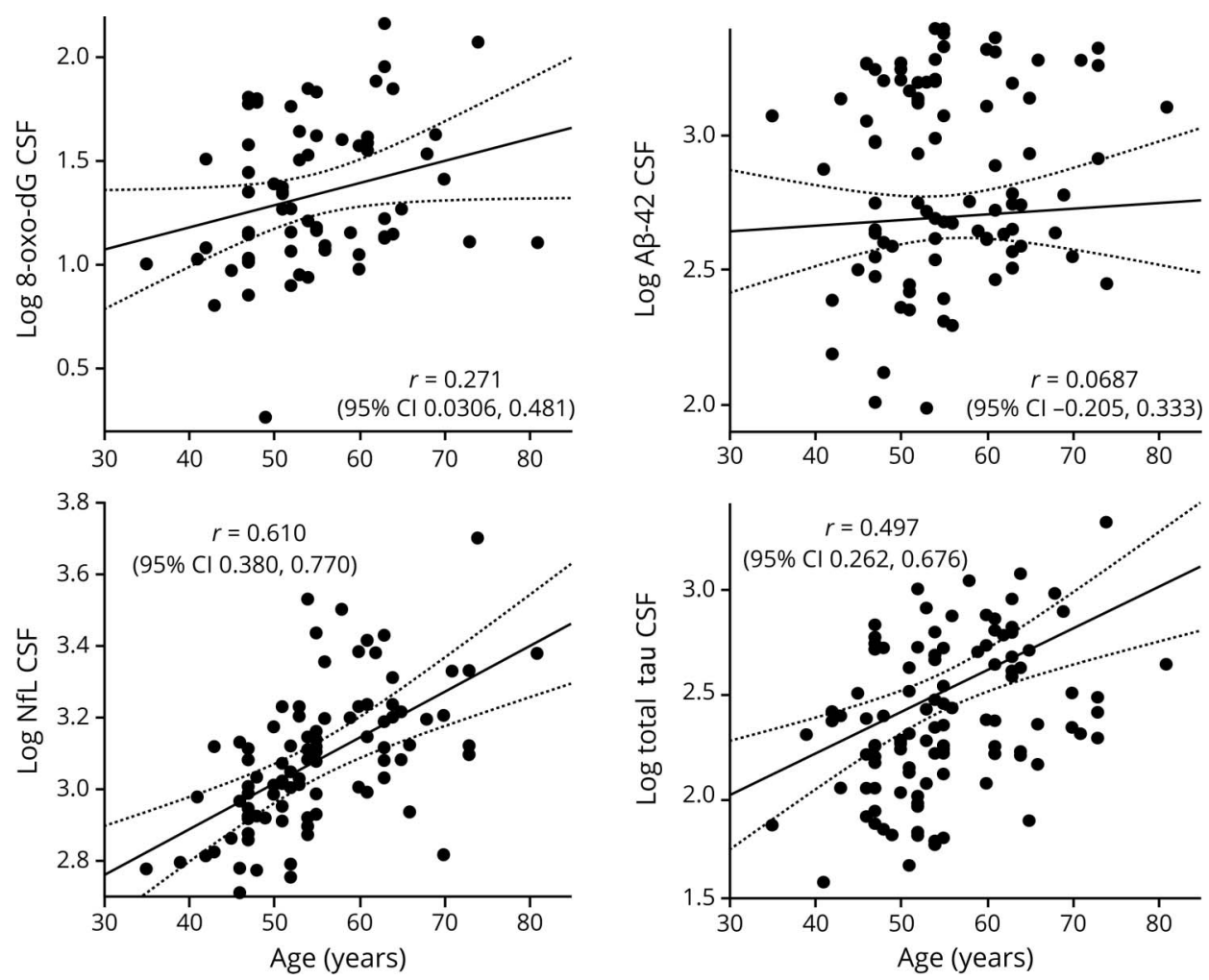

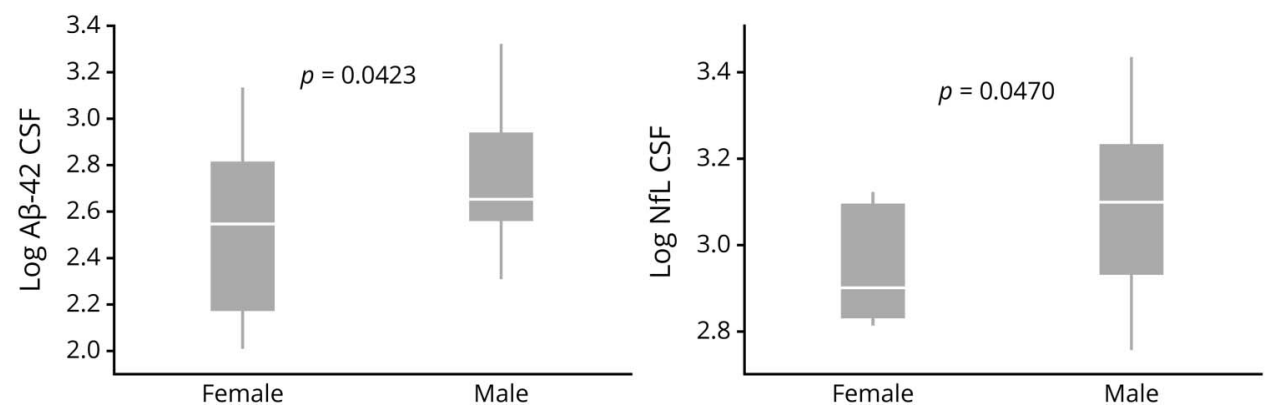

$\mathrm{dG}$ levels persisted after adjusting for history of d-drug exposure. None of the biomarkers was significantly associated with lifetime history of substance use disorder or hepatitis $\mathrm{C}$ virus serology.

\section{Discussion}

Age-related neurodegeneration in HIV has taken on expanded importance due to the increased longevity of $\mathrm{PWH}$ with successful ARV and because of the intersection of the HIV and AD epidemics. Neurodegeneration in PWH is associated with oxidative stress. Although the relationship between oxidative stress and neurodegeneration is well known, few studies have reported findings from CSF on it and none among PWH. Here we show that neurodegenerative biomarkers in CSF are related to increased oxidative stress as indexed by 8-oxo-dG levels in virologically suppressed $\mathrm{PWH}$. These findings suggest that oxidative stress related to $\mathrm{HIV}$ and/or ARV may contribute to neurodegeneration in aging $\mathrm{PWH}$.

Mitochondrial dysfunction may contribute importantly to increased oxidative stress in PWH on ARVs. HIV proteins and ARVs can damage mitochondria, which can generate reactive oxygen species (ROS). ${ }^{4,16-18}$ HIV proteins can also induce ROS generation as part of the inflammatory response. ${ }^{19}$ Thus, persistent low-level HIV protein expression or chronic exposure to ARV likely contributes to long-term exposure to ROS. ROS induce inflammatory gene expression and also inhibit mitochondrial-associated antiviral responses in glial cells. HIV proteins and ARV can induce mitochondria to generate ROS as part of the inflammatory response. ${ }^{17}$ Recent studies show that astrogliosis and inflammation in $\mathrm{AD}$ and in $\mathrm{PWH}$ may compromise mitochondrial homeostasis in neurons leading to neurodegeneration, perpetuating ROS-induced inflammation and neurodegeneration. ${ }^{18}$ Strategies that disrupt the cycle between oxidative stress, neuroinflammation, and neurodegeneration may be useful in slowing the aging process in PWH on ARVs.

The relationships we found were specific to CSF vs plasma biomarkers. This suggests that CSF provides a unique window into oxidative stress and neurodegeneration in the CNS. The specificity of the association of neurodegeneration biomarkers to DNA oxidation biomarkers, but not protein oxidation markers, may indicate mitochondrial dysfunction as a major causative factor. mtDNA is particularly susceptible to oxidative damage due to a lack of nucleosomes and proximity to ROS generated at the electron transport chain. ${ }^{20,21}$ Thus, oxidative stress caused by mitochondrial damage may first and predominantly affect mtDNA. Another potential explanation for the different associations of neurodegeneration markers with nucleic acid oxidation vs protein oxidation (protein carbonyls) is differences in rates of excretion of protein and DNA from healthy or dying cells or differences in degradation of these molecules inside the cells or in the extracellular space. These possibilities will need to be investigated in future studies.

The design of our study cannot discern whether oxidative stress is causing neurodegeneration or vice versa. These causal relationships could be validated in animal models or in vitro, for example, by exposing neurons in culture to oxidizing agents and measuring subsequent changes in markers of neurodegeneration or by evaluating oxidative stress levels in cells overexpressing $A \beta$ or tau. Implications for clinical management are not clear because the direction of causality is not known. The absence of links between biomarkers of neurodegeneration, oxidative stress, and neurocognitive impairment might be explained by the suggestion that these are early markers, altered before the onset of neurocognitive impairment. Future studies should examine whether longitudinal increases in 8-oxo-dG are related to evidence of worsening neurodegeneration in $\mathrm{PWH}$.

\section{Acknowledgment}

The CNS HIV Anti-Retroviral Therapy Effects Research was supported by awards N01 MH22005, HHSN271201000036C, HHSN271201000030C, and R01 MH107345 from the NIH. The CNS HIV Anti-Retroviral Therapy Effects Research (CHARTER) group is affiliated with Johns Hopkins University; the Icahn School of Medicine at Mount Sinai; University of California, San Diego; University of Texas, Galveston; University of Washington, Seattle; and Washington University, St. Louis; and is headquartered at the University of California, San Diego, and includes Directors: Robert K. Heaton, PhD, 
and Scott L. Letendre, MD; Center Manager: Donald Franklin, Jr.; Coordinating Center: Brookie Best, PharmD, Debra Cookson, M.P.H, Clint Cushman, Matthew Dawson, Ronald J. Ellis, $\mathrm{MD}, \mathrm{PhD}$, Christine Fennema Notestine, $\mathrm{PhD}$, Sara Gianella Weibel, MD, Igor Grant, MD, Thomas D. Marcotte, $\mathrm{PhD}$ Jennifer Marquie-Beck, M.P.H., and Florin Vaida, $\mathrm{PhD}$; Johns Hopkins University Site: Ned Sacktor, MD (PI), and Vincent Rogalski; Icahn School of Medicine at Mount Sinai Site: Susan Morgello, MD (PI), and Letty Mintz, N.P.; University of California, San Diego Site: J. Allen McCutchan, MD (PI); University of Washington, Seattle Site: Ann Collier, MD (Co-PI) and Christina Marra, MD (Co-PI) and Sher Storey, PA-C.; University of Texas, Galveston Site: Benjamin Gelman, MD, PhD (PI), and Eleanor Head, R.N., B.S.N.; and Washington University, St. Louis Site: David Clifford, MD (PI), and Mengesha Teshome, MD. The views expressed in this article are those of the authors and do not reflect the official policy or position of the US Government.

\section{Study funding}

This study is funded by NIH (R01MH107345).

\section{Disclosure}

The authors report no disclosures. Go to Neurology.org/NN for full disclosures.

\section{Publication history}

Received by Neurology: Neuroimmunology \& Neuroinflammation October 11, 2019. Accepted in final form August 31, 2020.

\section{Appendix Authors}

\begin{tabular}{lll}
\hline Name & Location & Contribution \\
$\begin{array}{l}\text { Ronald J. Ellis, } \\
\text { MD, PhD }\end{array}$ & $\begin{array}{l}\text { University of } \\
\text { California, San } \\
\text { Diego }\end{array}$ & $\begin{array}{l}\text { Designed and conceptualized the } \\
\text { study; analyzed the data; and } \\
\text { drafted the manuscript }\end{array}$ \\
\hline $\begin{array}{l}\text { David J. } \\
\text { Moore, PhD }\end{array}$ & $\begin{array}{l}\text { University of } \\
\text { California, San } \\
\text { Diego }\end{array}$ & $\begin{array}{l}\text { Interpreted the data and revised the } \\
\text { manuscript for intellectual content }\end{array}$ \\
$\begin{array}{l}\text { Erin E. } \\
\text { Sundermann, } \\
\text { PhD }\end{array}$ & $\begin{array}{l}\text { University of } \\
\text { California, San } \\
\text { Diego }\end{array}$ & $\begin{array}{l}\text { Interpreted the data and revised the } \\
\text { manuscript for intellectual content }\end{array}$ \\
\hline $\begin{array}{l}\text { Robert K. } \\
\text { Heaton, PhD }\end{array}$ & $\begin{array}{l}\text { University of } \\
\text { California, San } \\
\text { Diego }\end{array}$ & $\begin{array}{l}\text { Interpreted the data and revised the } \\
\text { manuscript for intellectual content }\end{array}$ \\
\hline $\begin{array}{l}\text { Sanjay Mehta, } \\
\text { MD }\end{array}$ & $\begin{array}{l}\text { University of } \\
\text { California, San } \\
\text { Diego }\end{array}$ & $\begin{array}{l}\text { Interpreted the data and revised the } \\
\text { manuscript for intellectual content }\end{array}$ \\
$\begin{array}{l}\text { Todd Hulgan, } \\
\text { MD }\end{array}$ & $\begin{array}{l}\text { Vanderbilt } \\
\text { University }\end{array}$ & $\begin{array}{l}\text { Interpreted the data and revised the } \\
\text { manuscript for intellectual content }\end{array}$ \\
\hline
\end{tabular}

Appendix (continued)

\begin{tabular}{lll}
\hline Name & Location & Contribution \\
\hline $\begin{array}{l}\text { David } \\
\text { Samuels, PhD }\end{array}$ & $\begin{array}{l}\text { Vanderbilt } \\
\text { University }\end{array}$ & $\begin{array}{l}\text { Interpreted the data and revised the } \\
\text { manuscript for intellectual content }\end{array}$ \\
\hline $\begin{array}{l}\text { Jerel A. Fields, } \\
\text { PhD }\end{array}$ & $\begin{array}{l}\text { University of } \\
\text { California, San } \\
\text { Diego }\end{array}$ & $\begin{array}{l}\text { Interpreted the data and revised the } \\
\text { manuscript for intellectual content }\end{array}$ \\
\hline $\begin{array}{l}\text { Scott L. } \\
\text { Letendre, MD }\end{array}$ & $\begin{array}{l}\text { University of } \\
\text { California, San } \\
\text { Diego }\end{array}$ & $\begin{array}{l}\text { Interpreted the data and revised the } \\
\text { manuscript for intellectual content }\end{array}$ \\
& &
\end{tabular}

\section{References}

1. Masia M, Padilla S, Fernandez M, et al. Oxidative stress predicts all-cause mortality in HIV-infected patients. PLoS One 2016;11:e0153456.

2. Zhang $\mathrm{Y}$, Wang M, Li H, et al. Accumulation of nuclear and mitochondrial DNA damage in the frontal cortex cells of patients with HIV-associated neurocognitive disorders. Brain Res 2012;1458:1-11.

3. Ivanov AV, Valuev-Elliston VT, Ivanova ON, et al. Oxidative stress during HIV infection: mechanisms and consequences. Oxid Med Cell Longev 2016;2016: 8910396.

4. Akay C, Cooper M, Odeleye A, et al. Antiretroviral drugs induce oxidative stress and neuronal damage in the central nervous system. J Neurovirol 2014;20:39-53.

5. Lewis W, Copeland WC, Day BJ. Mitochondrial dna depletion, oxidative stress, and mutation: mechanisms of dysfunction from nucleoside reverse transcriptase inhibitors. Lab Invest 2001;81:777-790.

6. Schweinsburg BC, Taylor MJ, Alhassoon OM, et al. Brain mitochondrial injury in human immunodeficiency virus-seropositive $(\mathrm{HIV}+)$ individuals taking nucleoside reverse transcriptase inhibitors. J Neurovirol 2005;11:356-364.

7. Markesbery WR, Lovell MA. DNA oxidation in Alzheimer's disease. Antioxid Redox Signal 2006;8:2039-2045

8. Wang J, Xiong S, Xie C, Markesbery WR, Lovell MA. Increased oxidative damage in nuclear and mitochondrial DNA in Alzheimer's disease. J Neurochem 2005;93: 953-962.

9. Cheignon C, Tomas M, Bonnefont-Rousselot D, Faller P, Hureau C, Collin F. Oxidative stress and the amyloid beta peptide in Alzheimer's disease. Redox Biol 2018;14: 450-464.

10. Zhao Y, Zhao B. Oxidative stress and the pathogenesis of Alzheimer's disease. Oxid Med Cell Longev 2013;2013:316523..

11. Schulz KL, Eckert A, Rhein V, et al. A new link to mitochondrial impairment in tauopathies. Mol Neurobiol 2012;46:205-216.

12. Rosengren LE, Karlsson JE, Karlsson JO, Persson LI, Wikkelso C. Patients with amyotrophic lateral sclerosis and other neurodegenerative diseases have increased levels of neurofilament protein in CSF. J Neurochem 1996;67:2013-2018.

13. Abdulle S, Mellgren A, Brew BJ, et al. CSF neurofilament protein (NFL) - a marker of active HIV-related neurodegeneration. J Neurol 2007;254:1026-1032.

14. Jessen Krut J, Mellberg T, Price RW, et al. Biomarker evidence of axonal injury in neuroasymptomatic HIV-1 patients. PLoS One 2014;9:e88591.

15. Heaton RK, Clifford DB, Franklin DR, Jr., et al. HIV-associated neurocognitive disorders persist in the era of potent antiretroviral therapy: CHARTER Study. Neurology 2010;75:2087-2096.

16. Ronaldson PT, Bendayan R. HIV-1 viral envelope glycoprotein gp 120 produces oxidative stress and regulates the functional expression of multidrug resistance protein-1 (Mrp1) in glial cells. J Neurochem 2008;106:1298-1313.

17. Cisneros IE, Erdenizmenli M, Cunningham KA, Paessler S, Dineley KT. Cocaine evokes a profile of oxidative stress and impacts innate antiviral response pathways in astrocytes. Neuropharmacology 2018;135:431-443.

18. Yin F, Sancheti H, Patil I, Cadenas E. Energy metabolism and inflammation in brain aging and Alzheimer's disease. Free Radic Biol Med 2016;100:108-122.

19. Pandhare J, Dash S, Jones B, Villalta F, Dash C. A novel role of proline oxidase in HIV 1 envelope glycoprotein-induced neuronal autophagy. J Biol Chem 2015;290: 25439-25451.

20. Hudson EK, Hogue BA, Souza-Pinto NC, et al. Age-associated change in mitochondrial DNA damage. Free Radic Res 1998;29:573-579.

21. Cline SD. Mitochondrial DNA damage and its consequences for mitochondrial gene expression. Biochim Biophys Acta 2012;1819:979-991. 


\section{Neurology \\ Neuroimmunology \& Neuroinflammation}

\section{Nucleic acid oxidation is associated with biomarkers of neurodegeneration in CSF in people with HIV \\ Ronald J. Ellis, David J. Moore, Erin E. Sundermann, et al. \\ Neurol Neuroimmunol Neuroinflamm 2020;7; \\ DOI 10.1212/NXI.0000000000000902}

This information is current as of October 14, 2020

Updated Information \&

Services

References

Subspecialty Collections

Permissions \& Licensing

Reprints including high resolution figures, can be found at:

http://nn.neurology.org/content/7/6/e902.full.html

This article cites 21 articles, 1 of which you can access for free at: http://nn.neurology.org/content/7/6/e902.full.html\#\#ref-list-1

This article, along with others on similar topics, appears in the following collection(s):

HIV

http://nn.neurology.org//cgi/collection/hiv

Information about reproducing this article in parts (figures,tables) or in its entirety can be found online at:

http://nn.neurology.org/misc/about.xhtml\#permissions

Information about ordering reprints can be found online: http://nn.neurology.org/misc/addir.xhtml\#reprintsus

Neurol Neuroimmunol Neuroinflamm is an official journal of the American Academy of Neurology.

Published since April 2014, it is an open-access, online-only, continuous publication journal. Copyright

Copyright (C) 2020 The Author(s). Published by Wolters Kluwer Health, Inc. on behalf of the American

Academy of Neurology.. All rights reserved. Online ISSN: 2332-7812.

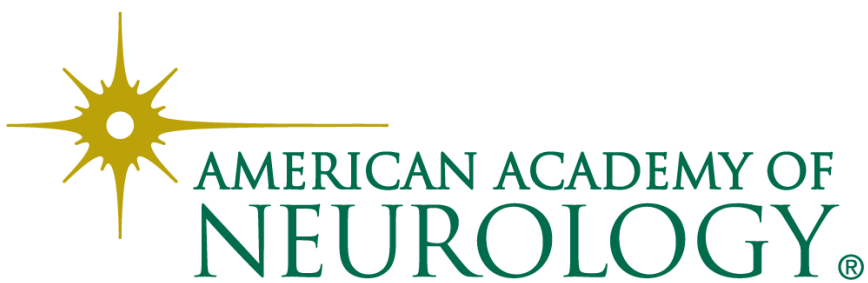

